In the Department of Botany, work on the anatomical determination of Pharaonic plant remains, carbohydrate and nitrogen metabolism, plant reactions to colchicine and $\beta$-indolylacetic acid, the effect of environmental factors on stomatal movements, the bacteriostatic effect of fungal metabolic products and organic chemicals and the ecology of Lake Edku are continuing; other investigations include a substitute colouring matter in butter, and the autecology of certain organisms. In the Department of Zoology, Prof. K. Mansour continued his study of some of the morphological and physiological aspects of the Lamellibrachiata (some of which have been reported in Nature), Prof. A. Naef his studies of the primitive Chordata, Dr. M. Waly his work of the Reptilia of Egypt and the fishes of the Nile, and Dr. F. Khalil the physiological investigation of the metabolism and excretion in some desert reptiles. Other investigations have covered the effect of triphenylchloroethylene on the development of the gonads of the frog, Egyptian spiders, the tympanic region of the Egyptian Insectivora, Chiroptera and Rodentia, yolk formation in the eggs of Mollusca, the chick embryo, etc. Work in the Department of Entomology has dealt with the biology of Egyptian insects, ecological studies of the insect fauna of freshwater ponds in the region of Cairo, and a biological and ecological survey of the Astero. lecaninæ. A note on the Library states that exchange activity with other universities and learned societies has now been resumed.

\section{Francis Amory Septennial Prize of the American Academy of Arts and Sciences}

UNDER the terms of a gift in the will of the late Francis mory of Beverly, Massachusetts, the American Academy of Arts and Sciences offers a substaytial prize for outstanding work on the allevjation or cure of diseases affecting the human reploductive organs. The gift provides a fund, the income of which may be awarded at seven-year intervals "as a prize and gold medal, or other token of honor or merit", to any individual or individuals for work of "extraordinary or exceptional merit" in this field. The next award is to be made in 1947. No formal applications and no essays or treatises from individuals are solicited; but suggestions will be welcome from any appropriate source that will be of aid to the Committee in making a wise selection. Recommendations may be addressed to Secretary, Amory Fund Committee, American Academy of Arts and Sciences, 28 Newbury Street, Boston, Massachusetts, U.S.A.

\section{Institution of Civil Engineers: Awards}

THE following medal, premiums and prizes of the Institution of Civil Engineers have been awarded for the papefs mentioned, which have been discussed, or publishled without oral discussion, during the session 1945.46. Baker Gold Medal: G. L. Groves, in recgnition of his work in connexion with the Ilford Tabe. Coopers Hill War Memorial Prize: G. A. Maunsell, "Menai Bridge Reconstruction". Telford Premiums : K. C. Appleyard and G. Curry, "Opencast Coal Production in Wartime"; R. F. Wileman and H. W. Clark, "The Measurement of the Discharges of the River-basins of the White Nile (Sudan) and Nene (Great Britain)"; M. R. James, "Renewal and Extension of Pumping Machinery for the Metropolitan Water Board"; A. E. Reid and F. W. Sully,
"The Construction of the King Feisal Bridge and the King Ghazi Bridge over the River Tigris at Baghdad" ; J. N. McFeeters, "Concrete Runways"; J.K. Fisher, Alfred Goode and C. E. Docker, "Some Problems in the Design and Construction of Large Airfields" ; J. D. Atkinson and George Cardiacos, "The Reconstruction of the Diyala Weir"; Robert Struthers and J. W. Lovatt, "Construction of a Heavy-Duty Concrete Runway" ; Rudolph Glossop and A. W. Skempton, "Particle-size in Silts and Sands"; C. H. Dobbie, "Some Sea Defence Works for Reclaimed Lands". Manby Premium : Rowland Nicholas, "Highway Planning, with Particular Reference to Traffic Capacities". Crampton Prize : C. T. Mitchell, "Some Economical Aspects of Modern Earthmoving Equipment"; George Graham and F. R. Martin, "Heathrow. The Construction of Highgrade Quality Concrete Paving for Modern Transport Aircraft". Trevithick Premiums': James Lorimer, "Some Uses of Explosives in Civil Engineering"; A. H. Toms, "Repairs to Railway Viaduct over London Road, Brighton, after Damage by Enemy Action in May 1943". Indian Premiums : Sir Claude Inglis, "Training Works construeted in the Rupnarain River in Bengal-after Model Experiments-to Prevent Further Bank Erosion endangering the Bengal-Nagpur Railway Line Linking Calcutta with Bombay and Madras"; C. G. Sexton, "The Construction of the Coronation Bridge over the Tista River, North Bengal, India" ; Philip Claxton, "The Still-Water Pocket Principle"'.

The following Medal and Prizes have been awarded to students for papers read before local associations. James Forest Medal and a Miller Prize: O. H. Senogles, "The Superficial Geological Deposits of the Manchester Area" (North-Western Association, Manchester). Miller Prizes : F. N. Kirby, "The Development of the Parsons Steam-Turbine" (Newcastle-onTyne and District Association); J. A. Williams, "A Survey of Current Practice on the Design of Storm. water Overflow Works" (Newcastle-on-Tyne and District Association); Wilfred Eastwood, "Surface Water Drainage from Roads and under British Conditions" (Yorkshire Association); G. S. Glendinning, "Distribution of Rainfall and Run-off from Catchment Areas" (Edinburgh and District Association) ; T. E. H. Williams, "Bridge Construction with Special Reference to Foundations" (Birmingham and District Association); R. W. Winkler, "Repairs to an Early Nineteenth Century Sea Wall" (Edinburgh and District Association); G. F. Clark, "Timber Bridges-Various Types and Their Construction" (Edinburgh and District Association); D. D. Treharne, "Opencast Coal Production" (South Wales and Monmouthshire Association).

\section{Announcements}

THE honorary degree of D.Sc. has been conferred by the University of Oxford on Prof. H. C. Urey, professor of chemistry and director of nuclear research in the University of Chicago.

Dr. Drxey, director of geological surveys, Nigeyla, has been appointed director of Colonial Geylogical Surveys, in which position he will be adviser on all geological matters to the Secretary of State for the Colonies.

Dr/Augustin E. RigGr has been appointed director of the Argentine (Bernardino Rivadavia) Museum of Natural Sciences at Buenos Aires. 